\title{
Dental Age: Effects of Estimating Different Events During Mineralization
}

\author{
Edward F. Harris*
}

\section{Department of Orthodontics, College of Dentistry, University of Tennessee Health Science Center, Memphis}

ABSTRACT The extent of tooth mineralization affords a
practical method for assessing an individual's biological
age. Dental age is useful for evaluating a child's
growth status, and for assessing the ages of subjects in
anthropological, forensic, and medicolegal settings.
Historically, some data have been collected from serial
studies (e.g., Stuart's Harvard Study, and the Burlington
Study) while most studies are cross-sectional, where each
child is examined just once. Serial and cross-sectional
studies traditionally have been used to estimate different
sorts of information, namely the onset at a stage and the

Tooth mineralization progresses in an invariant sequence, from crown tips through completion of the cementoenamel junction, and then through root formation, ending with closure of the root apices around the tooth's neurovascular bundles (e.g., Slavkin, 1974; Corliss, 1976). Moreover, the rate at which these processes of dentinogenesis and amelogenesis progress are well-regulated (e.g., Pelsmaekers et al., 1997; Parner et al., 2002; Merwin and Harris, 1998). Tooth formation is better buffered than bone formation (Greulich and Pyle, 1959; Garn et al., 1965), even though it can be modified by the environment (e.g., Toverud, 1957; Berkey et al., 2000; Alvarez et al., 1988; Alvarez, 1995). Tooth formation is perhaps the least-biased tissue by which to estimate the biological age of a child (Demirjian, 1986; Harris, 1998). This often is done clinically using radiographs (e.g., Liversidge, 2010) though direct examination can be used for archeological and forensic specimens (Johanson, 1971; Owsley and Jantz, 1983).

Tooth formation can be measured on a continuous scale as the mineralized portion lengthens (e.g., Liversidge and Molleson, 2004; Cardoso, 2009), but because this is timeintensive, and because of the morphological complexity of the tooth's three dimensions, it generally is preferable to use visual criteria to determine the grade of development. Grades are arbitrarily devised, with the intent of differentiating as many stages as possible (so finer distinctions can be made), but not so many that the observer cannot distinguish accurately between them. The two commonly used grading schemes are by Moorrees, Fanning and Hunt (1963) with 14 stages and by Demirjian, Tanner and Goldstein (1973) with 8 stages, though many other schemes have been developed (e.g., Nolla, 1960; Liliequist and Lundbert, 1971; Haavikko, 1973). The Moorrees scheme is popular but has been criticized because it requires the scorer to estimate final size (e.g., $\operatorname{root} 1 / 2$ formed, etc.). The average age in a stage, respectively. This paper discusses the differences of the analyses, and then presents an empirical comparison of two large sets of data on the lower third molar in American whites, showing how the conventional uses of serial data - that estimate the onset of an event-precede the age of occurrence derived from cross-sectional data (age at stage). Inter-group differences for tooth stages can exceed one year, so it is important to recognize the nature of the 'standards' available in the literature. Dental Anthropology 2011;24(2):59-63.

Demirjian system, in contrast, uses only observable criteria and now is perhaps the method of choice though, with only 8 grades, it lacks the potentially finer discrimination of Moorrees' 14 stages.

A pertinent question is how to develop normative standards from the data regardless of the grading scheme, and, more specifically, what sort of data have been collected. That is, are the data from a longitudinal growth study where the same children are examined periodically, or are the data from a cross-sectional study where the children are only examined once? These two sources traditionally been used to create different kinds of data that estimate different features of the growth process. The purpose of this paper is to discuss the two kinds of estimates (Smith (1991) describes others) and give an example of the practical differences.

\section{Longitudinal Studies}

There have only been a handful of studies where children-generally healthy and financially well-off-have been studied longitudinally, with multiple sorts of data collected at fixed intervals, generally 6 months or a year. Data have consisted of anthropometrics, x-rays, dental casts, and various sorts of intellectual tests. Well-known examples are the Bolton-Brush study in Cleveland, Ohio (Behrents and Broadbent, 1984), the Denver Child Growth Study, Colorado (McCammon, 1970), the Burlington growth study, a suburb of Toronto, Ontario (Thompson and Popovich, 1977), and the University School Growth Study from the University of Michigan, Ann Arbor (Riolo

${ }^{*}$ Correspondence to: Edward F. Harris, Department of Orthodontics, College of Dentistry, University of Tennessee, 870 Union Avenue, Memphis, TN 38163

E-mail: eharris@uthsc.edu 
et al., 1974; Moyers et al., 1976), though there are others (e.g., Jones and Bayley, 1941; Sanin and Savara, 1973). The complexity, commitment of money and manpower, and participant cooperation in such studies are enormous, and they are not likely to be repeated.

With longitudinal studies, each child is examined periodically, and the interest has been on identifying the onset of an event. Arbritrarily, consider Moorrees' stage 6 of crown completion (coded $\mathrm{Cr}_{\mathrm{c}}$ ) for the upper second molar. Each child's successive films are studied until that tooth exhibits $\mathrm{Cr}_{\mathrm{c}}$ (Fig. 1). For example, examining a child, $\mathrm{Cr}_{\mathrm{c}}$ had not been achieved at time $\mathrm{n}\left(\mathrm{t}_{\mathrm{n}}\right)$, but it is present at $t_{n+1}$. The actual event occurred sometime between $t_{n}$ and $t_{n+1}$, and the convention is to set the event at the midpoint between the two examinations, which is:

$$
t_{n}+\left(t_{n+1}-t_{n}\right) / 2
$$

It is unlikely that the achievement of $\mathrm{Cr}_{\mathrm{c}}$ occurred exactly at $t_{n+1}$, and the midpoint between examinations is the best guess of when the true event occurred (Dahlberg and Menegaz-Bock, 1958). The point is that this method estimates the onset of the event. In this case, at what chronological age does $\mathrm{Cr}_{\mathrm{c}}$ for the upper second molar occur in the sample under study? Onset cannot be determined from cross-sectional data (what Davenport (1931) termed "mass data"), but it can be approximated from the very low centiles of the age-at-occurrence.

\section{Cross-Sectional Studies}

Most studies do not have the luxury of following the same children over a span of time. In a typical anthropological setting, researchers examine subjects only once. It also is common to collect clinical records from a cohort of children where only one x-ray per child is available (e.g., Harris and McKee, 1990; Liversidge, 2010; Tunc and Koyuturk, 2008). Consider stage $\mathrm{Cr}_{c}$ for UM2 again. Perusal of a group of children will show that A) some have not yet attained this stage, B) some do exhibit the stage, and C) some have matured beyond this stage into a later stage (or completed formation). Plotting the data by chronological age (Fig. 1) shows a density plot that generally has a normal (Gaussian) distribution: a few younger children (early maturers) will exhibit the stage, the stage commonly occurs along a certain age span, and a few, older children still retain this stage (slow maturers). This is a distribution of when - in this sample - $\mathrm{Cr}_{c}$ is extant; Smith (1991) terms this "age of subjects in a stage." It is the average age when this stage of this tooth occurs in the sample. This statistic is not the same as the initiation of the stage as garnered from serial data. Parenthetically, information for the age of occurrence can be gotten from serial data, but it seldom is, and there is a statistical problem scoring the same person multiple times.

Given these two kinds of data, how much difference does it make? Is this an important distinction, or can it be ignored as a statistical nicety? It ought to make a pretty obvious difference.

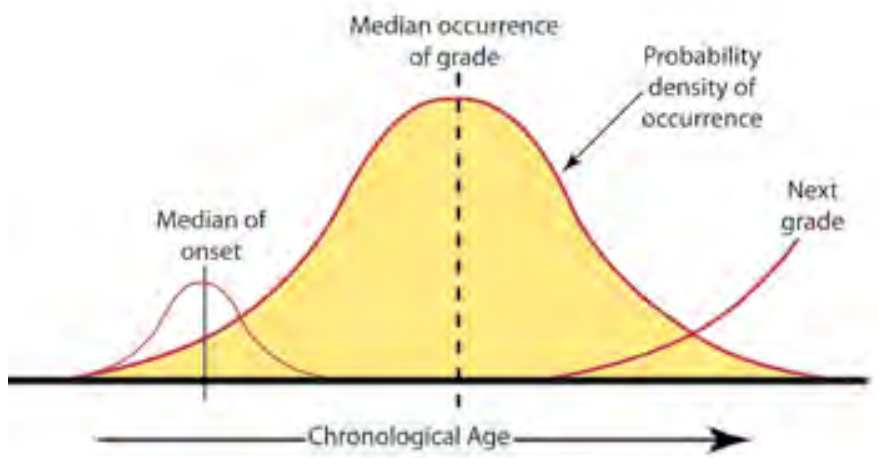

Fig. 1. Schematic showing the age distribution of when children exhibit a given stage of tooth formation. The probability density plot generally is normally distributed, ranging from early-maturing children at the younger ages up to the average age, and then tapering down to the slower-maturing children who are the last to exhibit the grade before maturing into the next grade. The median age-at-occurrence is the vertical dashed line. Serial studies can be used to estimate the onset of a grade (the distribution to the left of the diagram), but onset and median occurrence are quite different events. The hypothesized distribution of one stage is shown. The curve for onset is drawn smaller, but its age range can rival that of the age-at-occurrence, depending on the variability of dental ages in the sample. Intra-individual variability is considerable, so when the average child's tooth is at one stage, slow maturing children of the same chronological age will have stayed in a prior stage, and fast maturing children will be in a more advanced stage.

\section{MATERIALS AND METHODS}

The best known and one of the most popular 'standards' of tooth formation are those of Moorrees, Fanning and Hunt (1963; Harris and Buck, 2002). This study combined data from jaw x-rays of children from A) Harold C Stuart's Longitudinal Study of Child Growth and Development (Stuart et al., 1939; Stuart and Reed, 1959) and B) older children from the Fels Longitudinal Study (Yellow Springs, Ohio; Roche, 1992). The onset of World War II forced termination of the Stuart study because most of the medical personnel entered the Armed Forces, so Moorrees et al. collected their data on older children from the Fels Study. The x-rays were an oblique view of the jaws since the work predates the invention of panoramic x-ray machines (Graber, 1967).

Edward Hunt, the statistician on the project, used probit analysis to analyze the data (e.g., Finney, 1971). This required plotting chronological age against the cumulative percentage of the children attaining the grade in question. In the early 1960s, this generally was determined visually 


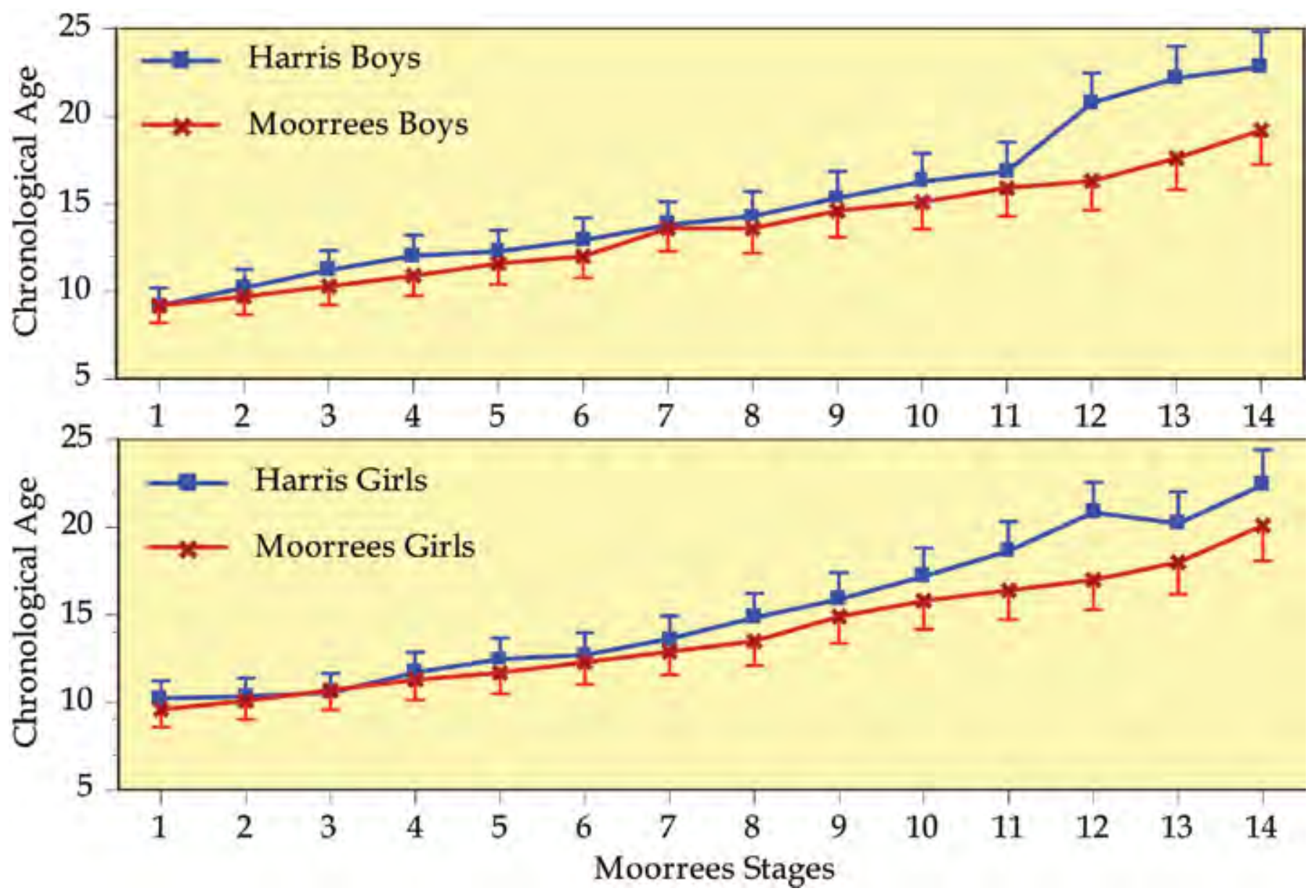

Fig. 2. Plots of the chronolological ages at each of Moorrees' 14 stages for the mandibular third molar as estimated by Moorrees et al. (1963) and from Mid-South whites (this study). The means differ by more than a year on average, and the apparent but incorrect interpretation is that the Moorrees sample developed faster. The real reason is that two different events are estimated; the Moorres values are for the onset of the grade, while the Harris estimates are for the average occurrence of the grade, which occur later.

from the graphed data. Unfortunately, how Moorrees' group actually performed the calculations is only described superficially. The data are provided separately by sex since Garn et al. (1958), among others, had documented sexual dimorphism in mineralization, which parallels that of tooth emergence (Cattell, 1928). Moorrees et al. (1963) chose to present their data graphically, so the actual values have to be interpolated from the diagrams (Harris and Buck, 2002).

The recent cohort described here consists of a crosssectional study of adolescents and young adults collected by the author who were phenotypically normal and were routine dental patients receiving treatment at the College of Dentistry, University of Tennessee, Memphis. Sample size was 1,870 (1,070 $\hat{\jmath}, 800$ क). These data were analyzed using survival analysis (Cox and Oakes, 1984; Allison, 1995) to obtain the medians and standard errors for each of Moorrees' 14 stages by sex. These statistics are the average ages in a stage, not the onset of the stage.

\section{RESULTS}

The Moorrees standards, published in 1963, were based on children largely from the 1930s, so it is anticipated that more recent children (i.e., the Harris data) - with better nutrition (CDC, 1999) and lessened morbidity-would be growing at faster tempos. Figure 2 shows the plots separately for boys and girls. The striking result is that the earlier, Moorrees group consistently formed their M3s faster from childhood (around 10 years of age) through completion of the root apices in the early 20s. The obvious question is why the results are so different? The mean difference is 1.6 years for boys and 1.4 years for girls. The facile (and incorrect) explanation is that these Mid-South children grew (and mineralized their LM3) much more slowly.

As alluded to, the main reason for the difference is that two different sorts of data are being compared, namely 
the onset of a stage (Moorrees) versus the average at which the stage occurs (Harris), which is Smith's "age of subjects in a stage." Of course, the onset predates the average occurrence, and the span of time for occurrence is greater than the onset. False interpretations stem from confusing these different events.

\section{DISCUSSION}

There is a long-term interest in how children grow, and, specifically, how the dentition forms (Krogman 1968; Demirjian (1986). Anthropologically, it is of interest whether some groups have a faster tempo of growth than others (perhaps the difference is adaptive). One wellknown example is between blacks and whites. Using tooth eruption (gingival emergence), Suk (1919) was probably the first to show that sub-Saharan blacks grow faster than whites (sometimes strikingly so, see Swinburne, 2005). Boas (1933) disseminated Suk's findings in the literature. Independently, Steggerda and Hill (1942) showed that eruption occurred earlier in American blacks than whites, and this difference has been confirmed and elaborated on by Garn and coworkers (Garn et al., 1972, 1973). Since tooth emergence is tied to the degree of tooth formation (Grøn, 1962), it follows that the two processes show the same ethnic differences. It seems most useful for such comparisons to use the median age-at-occurrence. This answers the question of whether the average-growing child from one group has a different rate of maturation than in a different group.

Clinically, a common use of dental age is to assess whether a child is growing at the "normal" rate: Is his/ her degree of tooth formation consistent with the child's chronological age? This is the basis of numerous studies of children with growth problems.

Since Moorrees' published standards (1963) are commonly cited and commonly available (the Journal of Dental Research is an open-access journal), researchers are prone to use these 'standards' to evaluate the status of children of interest. Since onset of a stage necessarily predates average occurrence of a stage (Smith, 1991), a child's degree of dental delay will be exaggerated when the Moorrees ages at onset are used, and, if the child' dental age is above-normal (Midtbø and Halse, 1992; Hass et al., 2001), dental age will be under-estimated when using these 'standards' because the comparison is between different events.

In sum, dental age is a practical method of gauging a child's degree of maturity. Because teeth form over a broad span of time-from the second trimester in utero through the onset of adulthood (Lunt and Law, 1974; McGettigan et al., 2011) - and all children can be assessed using the same criteria, the method is broadly applicable. However, it behooves the researcher to understand how the normative standards being used were obtained so proper comparisons can be made.

\section{LITERATURE CITED}

Allison PD. 1995. Survival analysis using SAS ${ }^{\circ}$ : A practical guide. Gary, NC: SAS Publishing.

Alvarez JO, Lewis CA, Saman C, Caceda J, Montalvo J, Figueroa ML, Izquierdo J, Caravedo L, Navia JM. 1988. Chronic malnutrition, dental caries, and tooth exfoliation in Peruvian children aged 3-9 years. Am J Clin Nutr 48:368-372.

Alvarez JO. 1995. Nutrition, tooth development, and dental caries. Am J Clin Nutr 61:410S-416S.

Behrents RG, Broadbent H Jr. 1984. A chronological account of the Bolton-Brush Growth Studies: In search of truth for the greater good of man. Privately printed, Case Western Reserve University, Cleveland

Berkey CS, Gardner JD, Frazier AL, Colditz GA. 2000. Relation of childhood diet and body size to menarche and adolescent growth in girls. Am J Epidemiol 152:446-452.

Boas F. 1933. Studies in growth, II. Hum Biol 5:429-444.

Cardoso HF. 2009. Accuracy of developing tooth length as an estimate of age in human skeletal remains: the permanent dentition. Am J Forensic Med Pathol 30:127133.

Cattell P. 1928. Dentition as a measure of maturity, Cambridge: Harvard University Press.

CDC. Achievements in public health, 1900-1999: safer and healthier foods. MMWR 1999;48:905-913.

Corliss CE. 1976. Patton's human embryology: elements of clinical development. New York: McGraw-Hill Book Company.

Cox DR, Oakes D. 1984. Analysis of survival data. London: Chapman and Hall.

Dahlberg AA, Menegaz-Bock RM. 1958. Emergence of the permanent teeth in Pima Indian children. J Dent Res 37:1123-1140.

Davenport CB. 1931. Individual vs. mass studies in child growth. Proc Am Philos Soc;70:381-389.

Demirjian A. 1986. Dentition. In: Falkner F, Tanner JM, eds. Human growth: a comprehensive treatise, 2nd ed. New York: Plenum, p. 269-298.

Demirjian A, Goldstein H, Tanner JM. 1973. A new system of dental age assessment. Hum Biol 45:211-27.

Finney DJ. 1971. Probit analysis, 3rd ed. Cambridge: Cambridge University Press.

Garn SM, Lewis AB, Blizzard RM. 1965. Endocrine factors in dental development. J Dent Res 44A:243-258.

Garn SM, Sandusky ST, Nagy JM, Trowbridge FL. 1973. Negro-Caucasoid differences in permanent tooth emergence at a constant income level. Arch Oral Biol 18:609-615.

Garn SM, Wertheimer F, Sandusky ST, McCann MB. 1972. Advanced tooth emergence in Negro individuals. J Dent Res 51:1506.

Graber TM. 1967. Panoramic radiography in orthodontic diagnosis. Am J Orthod 53:799-821.

Greulich WW, Pyle SI. 1959. Radiographic atlas of skeletal 
development of the hand and wrist, 2nd ed. Stanford, CA: Stanford University Press.

Grøn AM. 1962. Prediction of tooth emergence. J Dent Res 41:573-585.

Haavikko K. 1970. The formation and the alveolar and clinical eruption of the permanent teeth: An orthopantomographic study. Suom Hamm Toim 66:103-170.

Harris EF, Buck A. 2002. Tooth mineralization: a technical note on the Moorrees-Fanning-Hunt standards. Dental Anthropology 16:15-20.

Harris EF, McKee JH. 1990. Tooth mineralization standards for blacks and whites from the middle southern United States. J Forensic Sci 35;859-872.

Harris EF. 1998. Dental maturation. In: Ulijaszek SJ, Johnston FE, Preece MA, eds. The Cambridge encyclopedia of human growth. Cambridge: Cambridge University Press, $\mathrm{p}$ 45-48.

Hass AD, Simmons KE, Davenport ML, Proffit WR. 2001. The effect of growth hormone on craniofacial growth and dental maturation in Turner syndrome. Angle Orthod 71:50-59.

Johanson G. 1971. Age determination from human teeth. Odont Revy 22(suppl 22):1-126.

Jones HE, Bayley N. 1941. The Berkeley Growth Study. Child Develop 12:167-173.

Krogman WM. 1968. Biological timing and the dento-facial complex. ASDC J Dent Child 1968;35:175-185, 328-341, 377-381.

Liversidge HM, Molleson T. 2004.Variation in crown and root formation and eruption of human deciduous teeth. Am J Phys Anthropol 123:172-180.

Liversidge HM. Demirjian stage tooth formation results from a large group of children. Dental Anthropology 2010;23:16-24.

Lunt RC, Law DB. 1974. A review of the chronology of calcification of deciduous teeth. J Am Dent Assoc 89:599606.

McCammon RW. 1970. Human growth and development. Springfield: CC Thomas.

McGettigan A, Timmins K, Herbison P, Liversidge H, Jules Kieser J. 2011.Wisdom tooth formation as a method of estimating age in a New Zealand population. Dental Anthropology 24:33-41.

Merwin DR, Harris EF. 1998. Sibling similarities in the tempo of tooth mineralization. Arch Oral Biol 43:205210.

Midtbø M, Halse A. 1992. Skeletal maturity, dental maturity, and eruption in young patients with Turner syndrome. Acta Odontol Scand 50:303-312.

Moorrees CFA, Fanning EA, Hunt Jr EE. 1963. Age variation of formation stages in ten permanent teeth. J Dent Res 42:1490-1502.

Moyers RE, van der Linden FPGM, Riolo ML, McNamara JA Jr. 1976. Standards of human occlusal development. Monograph No. 5, Craniofacial Growth Series. Ann Arbor: Center for Human Growth and Development.
Owsley DW, Jantz RL. 1983. Formation of the permanent dentition in Arikara Indians: timing differences that affect dental age assessments. Am J Phys Anthropol 61:467-471.

Parner ET, Heidmann JM, Kjaer I, Vaeth M, Poulsen S. 2002. Biological interpretation of the correlation of emergence times of permanent teeth. J Dent Res 81:451454.

Pelsmaekers B, Loos R, Carels C, Derom C, Vlietinck R. 1997. The genetic contribution to dental maturation. J Dent Res 76:1337-1340.

Riolo ML, Moyers RE, McNamara JA Jr, Hunter WS. 1974. An atlas of craniofacial growth: cephalometric standards from the University School Growth Study, the University of Michigan. Monograph 2, Craniofacial Growth Series. Ann Arbor: Center for Human Growth and Development, University of Michigan.

Roche AF. 1992. Growth, maturation and body composition: the Fels longitudinal study 1929-1991. Cambridge: Cambridge University Press.

Sanin C, Savara BS. 1973. Factors that affect the alignment of the mandibular incisors: a longitudinal study. Am J Orthod 64:248-257.

Slavkin HC. 1974. Embryonic tooth formation: a tool for developmental biology. Oral Sci Rev p. 6-136.

Smith BH. 1991. Standards of human tooth formation and dental age assessment. In: Kelley MA, Larsen SP, editors. Advances in dental anthropology. New York: Wiley-Liss, p. 143-168.

Steggerda M, Hill TJ. 1942. Eruption time of teeth among whites, Negroes, and Indians. Am J Orthod 28:361-370.

Stuart HC, Reed RB. 1959. Longitudinal studies of child health and development-Series II. Description of project. Pediatrics 24:875-885.

Stuart HC et al. 1939. Studies from the Center for Research in Child Health and Development, School of Public Health, Harvard University. 1. The Center, the group under observation, sources of Information, and studies in progress, Monographs of the Society for Research in Child Development 4:serial no. 20.

Suk V. 1919. Eruption and decay of permanent teeth in whites and Negroes, with comparative remarks on other races. Am J Phys Anthropol 2:351-388.

Swinburne M. 2005. Advanced development. Br Dent J 198:628.

Thompson GW, Popovich F. 1977. A longitudinal evaluation of the Burlington growth centre data. J Dent Res 56 Spec No:C71-78.

Toverud G. 1957. The influence of war and post-war conditions on the teeth of Norwegian school children. II. Caries in the permanent teeth of children aged 7-8 and 12-13 years. Milbank Memorial Fund Quarterly 35:127196.

Tunc ES, Koyuturk AE. 2008.Dental age assessment using Demirjian's method on northern Turkish children. Forensic Sci Int 175:23-26. 